\title{
Technical Quality of a Mobile SPOC
}

\author{
https://doi.org/10.3991/ijim.v12i5.9093 \\ Naima Belarbi $\left.{ }^{\square}\right)$, Abdelwahed Namir, Nadia Chafiq, Mohammed Talbi \\ University Hassan II, Casablanca, Morocco \\ naima.belarbi-etu@etu.univh2c.ma
}

\begin{abstract}
Computer based Learning Environments are mainly shaped by emerging environments such as Massive Open Online Courses (MOOCs), SPOCS (Small Private Online Courses) and Mobile learning. This variety challenges the quality of the content delivered in these various environments. In Moroccan higher education, SPOCS is a trending topic widely used in its context of blended learning. The present work focuses on an SPOC delivered as a hybrid mobile app and on factors that define its technical quality. The objective is to propose a set of technical quality factors which are defined following a study of literature, focusing on frameworks, labels, practices that are used to assess the quality of e-learning environments, MOOCs, SPOCs and mobile applications. ISO standards for the quality software and the guidelines for the most dominant Mobile Operating Systems (Android/IOS/Windows phone) are also considered when defining these criteria. The proposed criteria can be twofold used: 1) to assess the technical quality of an existing mobile SPOC; 2) constitutes guidelines to increase the technical quality of a new mobile SPOC
\end{abstract}

Keywords-Quality assessment, Technical criteria, SPOC, Mobile App, ISO Standards.

\section{$1 \quad$ Introduction}

Small Private Online Courses (SPOCs) are a trending phenomenon in online learning thanks mainly to the fact that they aim at offering a tailor-made course intended for a small group of learners. Recently, SPOCs like MOOCs (Massive Online Open Courses) have revolutionized universities by supporting blended learning and flipped classroom learning. In the era of mobile technologies, developing mobile accessibility to SPOCs represents a real challenge to fulfilling the learning needs of mobile learners. Mobile technologies can enrich educational opportunities for learners and offer the possibility of extending the scope and the value of SPOCs by improving access to learning materials due mainly to some features such as flexibility to learn anywhere and anytime, interactivity, portability, popularization and personalization [1] and thus allow promoting collaborative learning and informal learning by maximizing learner interactions and dialogues [2].

In order to develop mobile dimension within an SPOC, it is extremely important to consider quality requirements and success factors that ensure a successful experience for learners before investment on development of such a new environment. 
The quality of e-learning systems is an emergent subject. In recent years, valuable studies and sophisticated approaches are available to deal with global guidelines, benchmarks and quality standard models for: mobile learning [3; 4], online education, e-learning [5, 6] and open education including MOOCs and Open Educative Resources (OERs) [7, 8 and 9]. As the authors are interested in SPOCs delivered as a mobile app, a few works on developing a common framework for evaluating the quality of SPOCs or mobile apps exists.

Even concept quality is complex and any discussion about it is challenging, the authors aim, by the present work, to contribute to exploring the quality characteristics that ensure success of such emergent environment namely SPOC mobile app.

\section{Objective}

The quality of e-learning, MOOCs and mobile apps concern many dimensions: Pedagogical, Technical, Sociocultural and Economic dimension. The pedagogical dimension has been widely treated in proposals frameworks quality. But when proposing an SPOC as a mobile app, be it native or hybrid mobile app, technical dimension and user experience are extremely important. The objective of this work is to propose a list of criteria as an instrument for approaching the technical quality in an SPOC which is delivered as a mobile app. To this end, the authors explore the previous studies and summarize the most based proposal quality frameworks for elearning, MOOCs, SPOCs and mobile apps. The issue of this article ought to prove to be useful to assess the technical quality of an existing SPOC mobile app and to staff concerned with the design and development of an SPOC mobile.

\section{$3 \quad$ Methodology}

The present work narrows the focus down as regards literature review pertaining mainly to the previous studies relevant to the quality of e-learning, MOOCs/SPOCS and mobile apps. The authors determine to explore frameworks with the view to benchmarking approaches used for assessing the quality of online courses and mobile learning. The literature study is concerned also with standards for the quality software and the guidelines for designing and developing mobile apps. For the Technical requirements, the authors are mainly inspired by the ISO/ IEC 25023: 2016 for software quality and by the guidelines for designing mobile apps for the most popular mobile operating systems (Android/IOS/Windows phone).

Both quantitative and qualitative analyses were performed to identify the most cited quality factors relevant to all dimensions of an SPOC mobile app. Then, the authors focused on the technical quality factors of a mobile app and apply Pareto law to identify the most relevant factors of technical quality of SPOC. Finally, the authors proposed a list of technical criteria that can be twofold: 1) to assess the technical quality of an existing SPOC mobile app 2) or to constitute a set of guidelines applicable to SPOC designers in order to develop its mobile version. 


\section{$4 \quad$ Results}

\subsection{Works on quality e-learning}

To address the question of the quality of e-learning, various innovative and participative processes initiatives and programs have been developed from the community of organizations, universities, associations and institutions through the world. Nowadays, valuable assurance quality Models, Benchmarks and standards for assessing quality in e-learning are available with the aim to ensure the quality and success factors of online courses [8]. In table 1, the authors summarize some frameworks and tools used to assess the quality in e-learning.

Table 1. Some Frameworks/Labels/Systems quality used to assess quality in e-learning

\begin{tabular}{|c|c|}
\hline Quality Model & Framework \\
\hline $\begin{array}{l}\text { E-xcellence1: } \\
\text { EADTU (the European } \\
\text { Association of Distance } \\
\text { Teaching Universities) } \\
\text { Netherlands }\end{array}$ & $\begin{array}{l}6 \text { sections: } \\
\text { (1) Strategic management; (2) Curriculum design; } \\
\text { (3) Course design; (4) Course delivery; (5) Staff support; (6) Student support }\end{array}$ \\
\hline $\begin{array}{l}\text { ACODE2 } \\
\text { (the Australasian Coun- } \\
\text { cil } \\
\text { of Open, Distance and e- } \\
\text { Learning) }\end{array}$ & $\begin{array}{l}8 \text { benchmarks: } \\
\text { (1) Institution-wide policy and governance for technology enhanced learning; } \\
\text { (2) Planning for institution-wide quality improvement of technology enhanced } \\
\text { learning; (3) Information technology systems, services and support for technolo- } \\
\text { gy enhanced learning; (4) The application of technology enhanced learning } \\
\text { services; (5) Staff professional development for the effective use of technology } \\
\text { enhanced learning; (6) Staff support for the use of technology enhanced learn- } \\
\text { ing; (7) Student training for the effective use of technology enhanced learning; } \\
\text { (8) Student support for the use of technology enhanced learning. }\end{array}$ \\
\hline $\begin{array}{l}\text { AVU3 The African } \\
\text { Virtual University }\end{array}$ & $\begin{array}{l}7 \text { criteria: } \\
\text { (1) Institutional Policies and Mission; (2) Program Design and Development; } \\
\text { (3) Course design and Development; (4) Learning Infrastructure and Resources; } \\
\text { (5) Learner Support and Progression; (6) Learner Assessment and Evaluation; } \\
\text { (7) Community Capacity Building Development and Engagement. }\end{array}$ \\
\hline $\begin{array}{l}\text { ROI4 } \\
\text { Rubric for Online In- } \\
\text { struction }\end{array}$ & $\begin{array}{l}6 \text { dimensions: } \\
\text { (1) Learner Support and Resources; (2) Online Organization and Design; (3) } \\
\text { Instructional Design and Delivery; (4) Assessment and Evaluation of Student } \\
\text { Learning; (5) Innovative Teaching with Technology; (6) Faculty Use of Student } \\
\text { Feedback. }\end{array}$ \\
\hline ECBCheck5 & $\begin{array}{l}6 \text { dimensions } \\
\text { (1) Information About and Organization of the programme; (2) Target group } \\
\text { Orientation; (3) Quality of the Content; (4) Programme/ Course Design; (5) } \\
\text { Media Design; (6) Technology }\end{array}$ \\
\hline Quality matters (QM)6 & $\begin{array}{l}8 \text { General Standards and } 43 \text { Specific Review Standards: } \\
\text { (GS1) Course Overview and Introduction; (GS2) Learning Objectives; }\end{array}$ \\
\hline
\end{tabular}

\footnotetext{
${ }^{1}$ http://e-xcellencelabel.eadtu.eu/

2 www.acode.edu.au

$3 \mathrm{http} / / /$ www.avu.org/avuweb/en/

4 https://www.csuchico.edu/eoi/

5 http://www.ecb-check.net/

$6 \mathrm{http}: / /$ www.qualitymatters.org/
} 


\subsection{Works on quality MOOCs}

Works relevant to the quality in MOOCs are an emergent area and various frameworks that deal with quality assessment are proposed in literature. It can be noted that the quality concept is complex (Quality assurance; Quality evaluation, Quality improvement, Quality enhancement...); frameworks used to assess MOOCs/SPOCs quality concern in general institutional level, Course level, Student level, Assessment level and Social learning level. Various Tools and practices are used to assess or approach quality (frameworks, Labels, Benchmarks, Dimensions, Factors, Criteria, Questionnaires, Checklist, Indicators, Metrics, Items...)

In the foremost frameworks proposed to assess MOOCs/SPOCs quality, the technical criteria were not meticulously expressed. The authors found, for example, the general term 'Technology', 'Course technology" 'media design'...Table 2 summarized main frameworks and practices used to assess quality in MOOCs with emphasizing relevant technical criteria to be considered in our tool

Table 2. Frameworks used to assess the quality in MOOCs

\begin{tabular}{|c|c|c|}
\hline $\begin{array}{c}\text { Refer- } \\
\text { ence/Year }\end{array}$ & Proposed/used Framework & Technical criteria \\
\hline [10] (2016) & $\begin{array}{l}3 \text { dimensions: } \\
\text { (1) Learning objectives (Potential dimen- } \\
\text { sion) (2) Learning realization (Process } \\
\text { dimension) (3)Learning achievements } \\
\text { (Result dimension) }\end{array}$ & $\begin{array}{l}\text { (2) Learning realization (Process dimension) } \\
\text { not explicit }\end{array}$ \\
\hline [11] (2015) & $\begin{array}{l}\text { Quality Matters (QM) Eight standards/43 } \\
\text { criterias } \\
\text { (1) Course overview and introduction } \\
\text { (2) Learning objectives } \\
\text { (3) Assessment and measurement } \\
\text { (4) Instructional materials } \\
\text { (5) Learner interaction and engagement } \\
\text { (6) Course technology } \\
\text { (7) Learner support } \\
\text { (8) Accessibility }\end{array}$ & $\begin{array}{l}\text { (GS6) Course Technology } \\
\text { Technologies required in the course are readily } \\
\text { obtainable. } \\
\text { The course technologies are current. } \\
\text { Links are provided to privacy policies for all } \\
\text { external tools required in the course. } \\
\text { (GS8) Accessibility and Usability. } \\
\text { Course navigation } \\
\text { Ease of use. } \\
\text { Accessibility } \\
\text { Course design } \\
\text { Readability. }\end{array}$ \\
\hline [12] (2014) & $\begin{array}{l}\text { 2 Dimensions / } 6 \text { Categories/74 items } \\
\text { (1) Pedagogical criteria } \\
\text { 1.1 Instructional design ( Lecture/ Organi- } \\
\text { zation } \\
\text { 1.2 Assessment ( e-assessment/peer-to- } \\
\text { peer assessment } \\
\text { (2) Technical Criteria } \\
\text { 1.1 User interface } \\
\text { 1.2 Video content } \\
\text { 1.3 Learning and social tools }\end{array}$ & $\begin{array}{l}\text { (2) Technical Criteria } \\
\text { 1.1 User interface } \\
\text { 1.2 Video content } \\
\text { 1.3 Learning and social tools } \\
\text { 1.4 Learning analytics }\end{array}$ \\
\hline
\end{tabular}




\begin{tabular}{|c|c|c|}
\hline & 1.4 Learning analytics & \\
\hline $\begin{array}{l}{[13](2014)} \\
{[14](2017)}\end{array}$ & $\begin{array}{l}\text { OPENUPED7: } \\
6 \text { sections: } \\
\text { (1) Strategic management; (2) Curriculum } \\
\text { design; (3) Course design; (4) Course } \\
\text { delivery; (5) Staff support; (6) Student } \\
\text { support } \\
8 \text { features: } \\
\text { (1) Openness to learners; OL; (2) Digital } \\
\text { openness; DO; (3) Learner-centered } \\
\text { approach; LC; (4) Independent learning; } \\
\text { IL; (5) Media-supported interaction; MI; } \\
\text { (6) Recognition options; RO; (7) Quality } \\
\text { focus; QF; (8) spectrum of diversity SD. }\end{array}$ & $\begin{array}{l}\text { (3) Course design: } \\
\text { Technical design } \\
\text { User interface } \\
\text { (4) Course delivery } \\
\text { 4.1 Technical infrastructure } \\
\text { 4.1.1 System design and architecture } \\
\text { 4.1.2 Technical infrastructure management } \\
\text { (5) Staff support } \\
\text { 5.1 Technical aspects } \\
\text { 5.1.1 Technical support } \\
\text { 5.1.2 Technical training } \\
\text { (6). Student support } \\
\text { 6.3. Technical support } \\
\text { 6.3.1. Online services availability } \\
\text { 6.3.2. Professional management of technical } \\
\text { support } \\
\text { 6.3.3. Online technical support system availa- } \\
\text { bility }\end{array}$ \\
\hline [15] (2015) & $\begin{array}{l}\text { COURSE SCAN questionnaire } \\
\text { 10 Dimensions/62 items: } \\
\text { (1) first Merill's instructional principles } \\
\text { focused on learning activities: } \\
\text { (1) Problem-centered; (2) Activation; (3) } \\
\text { Demonstration; (4) Application; (5) } \\
\text { Integration } \\
\text { Augmented by five further principles } \\
\text { focused on learning resources and learn- } \\
\text { ing supports: } \\
\text { (6) Collective knowledge; (7) Collabora- } \\
\text { tion; (8) Differentiation; (9) Authentic } \\
\text { resources; (10) Feedback }\end{array}$ & Instructional principles \\
\hline [16] (2014) & $\begin{array}{l}10 \text { dimensions (Improvement quality) } \\
\text { (1).Interaction, (2) Collaboration; (3) } \\
\text { Motivation; (4) Network of Opportunities/ } \\
\text { Future directions; (5) Pedagogy; (6) Con- } \\
\text { tent; (7) Assessment; (8) Usability; (9) } \\
\text { Technology; (10) Support for Learners. }\end{array}$ & (8) Usability; (9) Technology \\
\hline [6] (2014) & $\begin{array}{l}10 \text { quality Benchmarks } \\
\text { (1) Institutional support (vision, planning, } \\
\& \text { infrastructure), (2) Course development, } \\
\text { (3) Teaching and learning (instruction), } \\
\text { (4). Course structure, (5) Student support, } \\
\text { (6) Faculty support, (7) Technology, (8) } \\
\text { Evaluation, (9) Student assessment, (10) } \\
\text { Examination security. }\end{array}$ & (7) Technology \\
\hline [17] (2014) & $\begin{array}{l}7 \text { categories/ } 71 \text { indicators } \\
\text { (1) Core requirements; (2) Structure } \\
\text { participant; (3) Requirements; (4) As- } \\
\text { signments; (5) Media design; (6) Commu- } \\
\text { nication; (7) Resources. }\end{array}$ & (5) media design; (6) communication \\
\hline [18] (2017) & $\begin{array}{l}10 \text { Indicators high quality } \\
\text { (1) Accessibility; (2) Flexibility; (3) }\end{array}$ & $\begin{array}{l}\text { (1) Accessibility; (2) Flexibility; (3) Interactiv- } \\
\text { ity; (4) personalization; (7) Use of media (10) }\end{array}$ \\
\hline
\end{tabular}

${ }^{7}$ http://www.openuped.eu/quality-label 


\begin{tabular}{|l|l|l|}
\hline & $\begin{array}{l}\text { Interactivity; (4) Personalization; (5) } \\
\text { Transparency; (6) Open and shared con- } \\
\text { tent; (7) Use of media; (8) Pedagogical } \\
\text { enhancement; (9) Reflection; (10) Social } \\
\text { learning. }\end{array}$ & Social learning. \\
\hline$[19](2013)$ & $\begin{array}{l}\text { 7C framework design assurance quality } \\
\text { (1) Conceptualize; (2) Capture; (3) Com- } \\
\text { municate; (4) Collaborate; (5) Consider; } \\
\text { (6) Combine; (7) Consolidate. }\end{array}$ & $\begin{array}{l}\text { The 7Cs of Learning Design framework aims } \\
\text { to provide teachers with the guidance and } \\
\text { support they need to make more pedagogically } \\
\text { informed design decisions. }\end{array}$ \\
\hline
\end{tabular}

\subsection{Standards on quality software}

The authors are inspired by the standard ISO/IEC 25023:2016 in the present work. This standard has been defined by International Organization for Standardization (ISO) and IEC (the International Electrotechnical Commission) in software engineering area and concerns quality of a product/software. Because the quality model is generic, it is possible to apply it to any software product by tailoring to a specific purpose. Table 3 reports the most known Standards which deal with quality and guidelines for mobile operating systems:

Table 3. Standards on quality software

\begin{tabular}{|l|l|}
\hline \multicolumn{1}{|c|}{ ISO 9000/ISO 8402 } & \multicolumn{1}{c|}{ Standards } \\
\hline $\begin{array}{l}\text { ISO/IEC 25023:2016 Systems and } \\
\text { software Quality Requirements and } \\
\text { Evaluation (SQuaRE) }\end{array}$ & $\begin{array}{l}\text { Measurement of system and software product quality: provides } \\
\text { measures including associated measurement functions for the } \\
\text { quality characteristics in the product quality model:(Functionality, } \\
\text { Performance, Compatibility Usability Reliability, Security, Main- } \\
\text { tainability, Portability) }\end{array}$ \\
\hline ISO/ IEC 9126-1 & $\begin{array}{l}\text { A quality model that comprises six characteristics and 27 sub- } \\
\text { characteristics of software product quality. Functionality, Usabil- } \\
\text { ity, Maintainability, Reliability, Portability. Efficiency. }\end{array}$ \\
\hline Flat design & Guidelines for IOS mobile app design \\
\hline Material Design & Guidelines Android/Windows phone mobile app \\
\hline
\end{tabular}

\subsection{Works on quality mobile apps}

Works relevant to mobile apps quality reflect the diversity of frameworks used to describe or to assess the quality of a mobile app. In Table 4, are reported the main criteria or dimensions quality of a mobile application/software from the relevant articles reviewed.

Table 4. Criteria quality of a mobile application / software from the relevant reviewed articles

\begin{tabular}{|l|l|}
\hline \multicolumn{1}{|c|}{ Reference/Year } & \multicolumn{1}{c|}{ Proposed/used Framework } \\
\hline$[3](2016)$ & $\begin{array}{l}5 \text { dimensions: Functionality, Accessibility, Interactivity, Ease of use, Interface } \\
\text { Design }\end{array}$ \\
\hline$[20](2015)$ & 5 dimensions: Functionality, Usability, Dependability, Performance, Availability \\
\hline$[21](2016)$ & 13 dimensions: Functionality, Interface Design, Usability, Performance, Availa- \\
\hline
\end{tabular}




\begin{tabular}{|l|l|}
\hline & $\begin{array}{l}\text { bility, Quick Response, Flexibility, Scalability, Maintainability, Reliability, Con- } \\
\text { nectivity, Security, User interface }\end{array}$ \\
\hline [4] (2016) & $\begin{array}{l}\text { 8 dimensions: Functionality, Usability, Performance, Security, Communication, } \\
\text { Portability, Support. Pedagogical }\end{array}$ \\
\hline [22] (2015) & $\begin{array}{l}4 \text { criteria/9 characteristics/39 requirements: } \\
\text { Technical/Pedagogical/Economic/Socio-Cultural) : } \\
\text { Functionality,Security, Performance, Pedagogical, Usability, Support, Service } \\
\text { Level, Communication, Portability }\end{array}$ \\
\hline [23] (2013) & $\begin{array}{l}\text { 9 dimensions: Functionality, Usability, Performance, Security, Communication, } \\
\text { Portability, Service level, Support, pedagogical }\end{array}$ \\
\hline [24] (2013) & $\begin{array}{l}\text { criteria and 9 characteristics and 44 requirements: } \\
\text { Functionality, Security, Performance, Pedagogical, Usability, Support, Service } \\
\text { Level, Communication, Portability. }\end{array}$ \\
\hline [25] (2017) & $\begin{array}{l}5 \text { dimensions: pedagogy, Technical Usability, Connectivity, Contextuality, con- } \\
\text { tent }\end{array}$ \\
\hline ISO/ IEC 9126 & $\begin{array}{l}6 \text { dimensions: Functionality, Usability, Maintainability, Reliability, Portability. } \\
\text { Efficiency }\end{array}$ \\
\hline ISO/ IEC 25023: 2016 & $\begin{array}{l}9 \text { dimensions: Functionality, Usability, Performance, Maintainability, Reliability, } \\
\text { Security, Portability. Efficiency, Compatibility }\end{array}$ \\
\hline
\end{tabular}

Figure 1 shows criteria quality for mobile application/software as they were cited in articles reviewed classified by frequency of their occurrence.

ISO 25023:2016

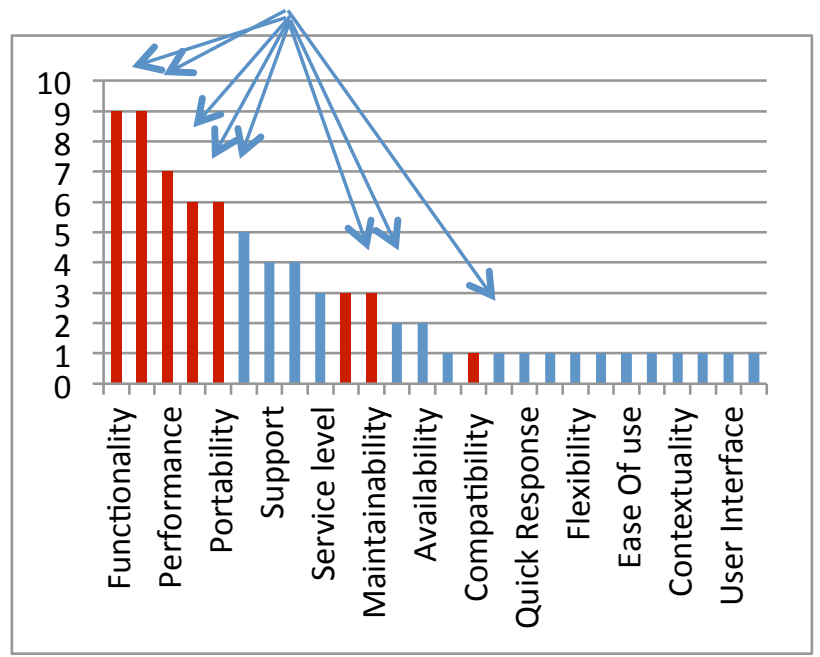

Fig. 1. Criteria quality for mobile application/software

\section{Discussion}

As the present work deals with technical criteria, the authors disregard the following criteria in the subsequent analysis: 
- Pedagogy (e.g. pedagogical strategy, motivation, learner, multimedia, and assessment) from [4, 22, 23, 24 and 25]

- Support and service level from [22, 23 and 24] which are considered as economic criteria

- Support from [4] considered as socioeconomic criterion

- Contextuality from [25] which means authenticity and learning in different contexts

- Content from [25] (e.g., curricular fit, scope, validity, sequence, and language)

- Communication from [4, 22, 23 and 24] considered as socio-cultural criterion

- For the criterion Usability, as it is a qualitative criterion and includes both technical and nontechnical aspects, the authors retain it in the present analysis and they consider several technical requirements which could affect usability such as the design of user interface, navigation...

- In [23, 24] Usability is considered as a pedagogical criterion but when considering its meaning in the relevant works, the authors found that user interface is the most considered when evaluating this criterion.

- The authors also considered that the criterion Interface Design from [3] is similar to the criterion User interface from [21].

- To identify the most important technical criteria relevant to the articles reviewed. The authors proposed to plot the diagram corresponding to the variant $\mathrm{ABC}$ of the Pareto law (see Figure 2) to highlight the most important criteria that affect the quality of a mobile application. The authors transfer generic concepts phenomenon and causes when using Pareto law in our case, the phenomenon considered is the quality of a SPOC mobile app and the causes correspond to the criteria.

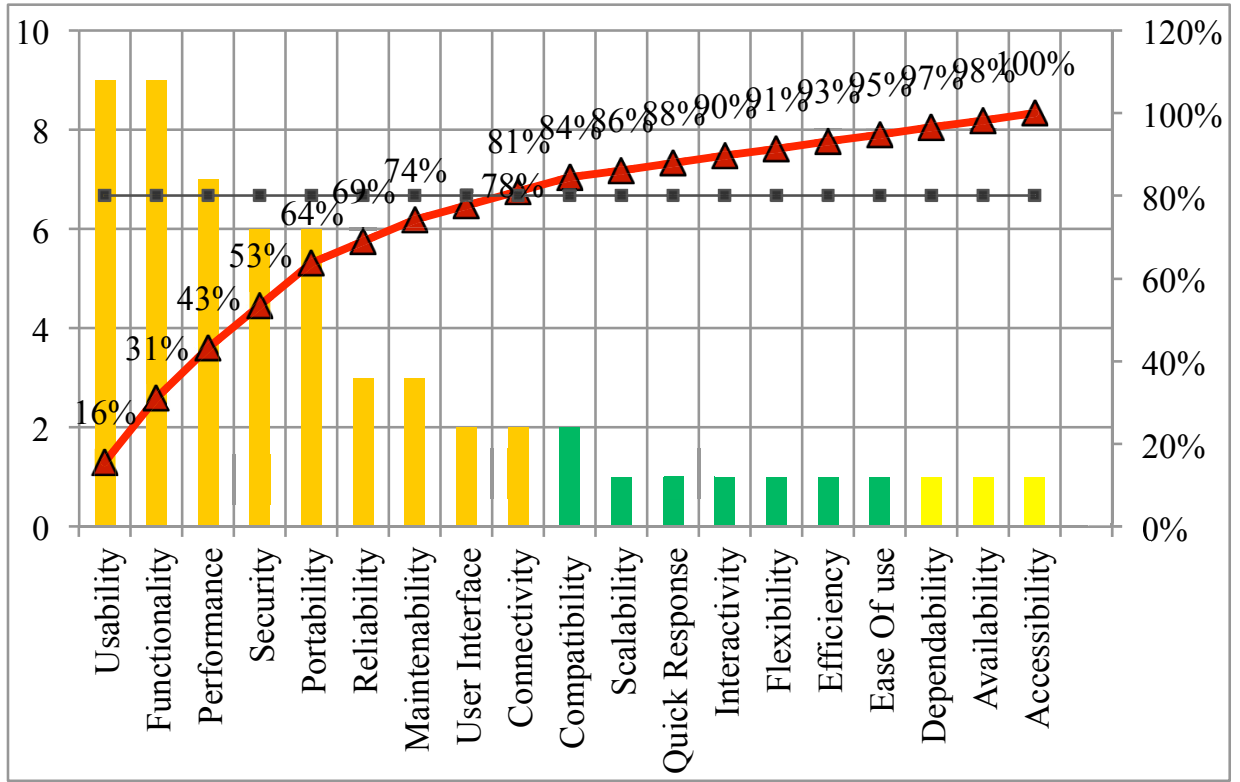

Fig. 2. Pareto diagram for more relevant Technical criteria quality for mobile app 
The Pareto diagram emphasizes the importance of focusing on the criteria from class A. As mentioned above, User Interface is the major technical criteria to consider in Usability criteria. It is also found that criteria from ISO/IEC 25023:2016 standards are mainly represented in the result found in the present work. Finally, to assess an SPOC mobile app quality, the authors propose the framework namely: User Interface, Functionality, Performance, Security, Portability, Reliability, Maintainability and Connectivity.

\section{Proposed Technical Criteria}

Each criteria of proposed framework is categorized into sub-criteria or Items to be checked so as to potentially approach the technical quality when designing an SPOC delivered as a mobile app (Table 5)

Table 5. Proposed Technical Criteria and sub-criteria

\begin{tabular}{|c|c|}
\hline Technical Criteria & Sub-criteria/Items \\
\hline User Interface & $\begin{array}{l}\text {-Visual design (typography, Colors, Animations) } \\
\text {-Layout and organization (Homogenous (Lisibility (Negative blank, Information } \\
\text { Hierarchy...), Orientation (portrait/landscape), ) } \\
\text {-Navigation (Accessible (tab bars, Top navigation, Hamburger Menu...), Intuitive } \\
\text { (gesture and moving device) design (Orientation: Horizontal/vertical; Haut/bas), } \\
\text { Input mode: More touch than click) } \\
\text {-Accessibility (Personalization (Fonts, Colors, Size), Alternative resources, Load } \\
\text { files, Offline access ) } \\
\text {-Contents (Video (Quality, duration, Format, Allow various speed ), Image (Resolu- } \\
\text { tion, size, Format), Labels (Image, Icones, Typography), Audio (Format, duration), } \\
\text { Links (Label), Text (Typography, color), Icons (Design, label), Additional Re- } \\
\text { sources (format, utility, emplacement)) }\end{array}$ \\
\hline Functionnality & $\begin{array}{l}\text {-Include Messaging strategy (push notifications, in-app notifications, } \\
\text { Course Announcements) } \\
\text {-Include various communication types (Student-student, student-teacher, Real-time } \\
\text { chat, synchronous or asynchronous (forum, email)) } \\
\text {-Include Social Tools (Technical Support (installation, configura- } \\
\text { tion, upgrade, error correction) } \\
\text {-Include Analytics (track users, collect outcomes data) } \\
\text {-Consideration of Physical constraints (Battery management,Memory, anagement, } \\
\text { Storage management mechanism, Connectivity management (wifi, 2G, 3G, 4G, } \\
\text { offline mode...)) } \\
\text {-Searching functionality } \\
\text {-Capability to identify technological requirements } \\
\text {-Provide easy-to-find links to support services }\end{array}$ \\
\hline Security & $\begin{array}{l}\text {-Authentification } \\
\text {-Autorisation } \\
\text {-Include input validation } \\
\text {-Uses tools and setting for safeguarding sensitive data } \\
\text {-Uses tools for files protection } \\
\text {-Ensure the integrity of data } \\
\text {-Ensure privacy and confidentiality of the data stored } \\
\text {-Session attack protection }\end{array}$ \\
\hline Performance & -Response time (of First Screen, UI transition, Loading time) \\
\hline
\end{tabular}




\begin{tabular}{|c|c|}
\hline & $\begin{array}{l}\text {-Availability (anytime, anywhere ) } \\
\text {-Battery consumption } \\
\text {-Memory consumption } \\
\text {-SPOC mobile app size }\end{array}$ \\
\hline Reliability & $\begin{array}{l}\text {-Stability after: } \\
\text {-abnormal Close } \\
\text {-battery life } \\
\text {-Disconnection } \\
\text {-User fault } \\
\text {-Backup when low battery } \\
\text {-Recovery after log-out/ disconnection }\end{array}$ \\
\hline Maintainability & $\begin{array}{l}\text {-Easy to debug } \\
\text {-Easy to modify } \\
\text {-Easy to Upgrade }\end{array}$ \\
\hline Portability & $\begin{array}{l}\text {-Easy to setup } \\
\text {-System adaptation (IOS, Android, ...) } \\
\text {-Device adaptation (Smartphone, Tablet,...) } \\
\text {-Different browsers Support }\end{array}$ \\
\hline Connectivity & $\begin{array}{l}\text {-Accommodates a wide range of connectivity: wifi, } 3 \mathrm{G} \text {, offline } \\
\text {-Allow Sharing content }\end{array}$ \\
\hline
\end{tabular}

\section{$7 \quad$ Conclusion and future works}

The present study aims at proposing a list of criteria that address as much as possible all the relevant technical aspects when designing SPOCs mobile. The proposed criteria must support educators designing an SPOC delivered as a mobile app. In order to complete and validate the proposed criteria and to understand the strength and weakness of its relevant categories and items, the authors intend to experiment it to design an SPOC as a mobile app as a course delivered in blended learning. This list must also carry out forthcoming new technical ideas. The authors consider the criteria list as a first starting point, which has to be improved or adapted in their on-going works.

\section{$8 \quad$ References}

[1] Kaplan, A. M., \& Haenlein, M. (2016). Higher education and the digital revolution: About MOOCs, SPOCs, social media, and the Cookie Monster. Business Horizons, 59(4), 441450. https://doi.org/10.1016/j.bushor.2016.03.008

[2] Jiugen, Y., \& Ruonan, X. (2016, August). Mobile terminal based mobile learning system design. In Computer Science \& Education (ICCSE), 2016 11th International Conference on IEEE, 699-703.

[3] Almaiah, M. A., \& Man, M. (2016). Empirical investigation to explore factors that achieve high quality of mobile learning system based on students' perspectives. Engineering Science and Technology, an International Journal, 19(3), 1314-1320. https://doi.org/10.1016/ j.jestch.2016.03.004

[4] Soad, G. W., Duarte Filho, N. F., \& Barbosa, E. F., (2016, October). Quality evaluation of mobile learning applications. In Frontiers in Education Conference (FIE), 2016 IEEE. 1-8. 
[5] Peres, P., Lima, L., \& Lima, V. (2014). b-learning quality: Dimensions, criteria and pedagogical approach. FormaMente: Rivista internazionale di ricerca sul futuro digitale, 12014, 117.

[6] Butcher, N., \& Wilson-Strydom, M. (2014), A Guide to Quality in Online Learning, Academic Partnership, Dullas, 2014.

[7] Gamage, D., Fernando, S., \& Perera, I, (2015). Quality of MOOCs: A review of literature on effectiveness and quality aspects, 8th International Conference on Ubi-Media Computing (UMEDIA) 2015, Colombo.

[8] Ossiannilsson, E., Williams, K., Camilleri, A., \& Brown, M. (2015). Quality models in online and open education around the globe. Oslo: The International Council for Open and Distance Education (ICDE).

[9] Ghislandi, P. M. M. (2016). "The fun they had" or about the quality of MOOC. Journal of e-Learning and Knowledge Society, 12(3).

[10] Stracke, C. M. (2016). MOOCs are dead! - Open Education and the Quality of Online Courses Towards a Common Quality Reference Framework, Proceedings EDEN 2016 Annual Conference, 215-221.

[11] Lowenthal, P., \& Hodges, C. (2015). In search of quality: Using Quality Matters to analyze the quality of massive, open, online courses (MOOCs). The International Review of Research in Open and Distributed Learning, 16(5). https://doi.org/10.19173/irrodl. v16i5.2348

[12] Yousef, A. M. F., Chatti, M. A., Schroeder, U., \& Wosnitza, M. (2014, July). What drives a successful MOOC? An empirical examination of criteria to assure design quality of MOOCs. In Advanced Learning Technologies (ICALT), 2014 IEEE 14th International Conference on, 44-48. IEEE.

[13] Rosewell, J., \& Jansen, D. (2014). The OpenupEd quality label: benchmarks for MOOCs. INNOQUAL: The International Journal for Innovation and Quality in Learning, 2(3), 88100

[14] Jansen, D., Rosewell, J., \& Kear, K. (2017). Quality Frameworks for MOOCs. In Open Education: from OERs to MOOCs, Springer Berlin Heidelberg, 261-281. https://doi.org/10.1007/978-3-662-52925-6_14

[15] Margaryan, A., Bianco, M., \& Littlejohn, A. (2015). Instructional quality of massive open online courses (MOOCs). Computers \& Education, 80, 77-83. https://doi.org/10.1016/ j.compedu.2014.08.005

[16] Gamage, D., Perera, I., \& Fernando, S. (2014). Effectiveness of eLearning through MOOC: lessons learnt in selecting a MOOC. In The 22nd International Conference on Computers in Education (ICCE 2014).

[17] Ebner, M., Lackner, E., \& Kopp, M. (2014, October). How to MOOC? A pedagogical guideline for practitioners. In The International Scientific Conference eLearning and Software for Education (Vol. 4, p. 215).

[18] Ossiannilsson, E., Altınay, Z., \& Altınay, F. (2017). Towards Fostering Quality in Open Online Education Through OER and MOOC Practices. In Open Education: from OERs to MOOCs, 189-204. Springer Berlin Heidelberg.

[19] Conole, G. (2016). MOOCs as disruptive technologies: strategies for enhancing the learner experience and quality of MOOCs.RED. Revista de Educación a Distancia, (50). https://doi.org/10.6018/red/50/2

[20] Sarrab, M., Hafedh, A. S., \& Bader, A. M. (2015). System Quality Characteristics for Selecting Mobile Learning Applications. Turkish Online Journal of Distance Education. https://doi.org/10.17718/tojde.83031

[21] Sarrab, M., Elbasir, M., \& Alnaeli, S. (2016). Towards a quality model of technical aspects for mobile learning services: An empirical investigation. Computers in Human Behavior, 55, 100-112. https://doi.org/10.1016/j.chb.2015.09.003 
[22] Baloh, M., Zupanc, K., Košir, D., Bosnić, Z., \& Scepanovic, S. (2015, June). A quality evaluation framework for mobile learning applications. In Embedded Computing (MECO), 2015 4th Mediterranean Conference IEEE, 280-283.

[23] Duarte Filho, N. F., \& Barbosa, E. F. (2013, October). A contribution to the quality evaluation of mobile learning environments. In Frontiers in Education Conference, 2013 IEEE, 379-382.

[24] Barbosa, E. F. (2013, March). A requirements catalog for mobile learning environments. In Proceedings of the 28th Annual ACM Symposium on Applied Computing, 1266-1271.

[25] Baran, E., Uygun, E., \& Altan, T. (2017). Examining Preservice Teachers' Criteria for Evaluating Educational Mobile Apps. Journal of Educational Computing Research, 54(8), 1117-1141. https://doi.org/10.1177/0735633116649376

\section{Authors}

Naima Belarbi is an Engineer in Automatic and Computer from Mohammadia School of Engineers (EMI Rabat) Morocco and a Teacher trainer in Regional Education and Training Trades Center (CRMEF) Casablanca. She is also a PhD student in Laboratory of Technological Information and Modelisation (LTIM) -Faculty of Sciences Ben M'Sik, University Hassan II - Casablanca, Morocco. Her area of interest: Blended learning, MOOCS, SPOCs, Mobile learning, Adaptive learning, Data Science.

Nadia Chafiq is a PhD in Educational Technology. She is a Professor at Faculty of Sciences Ben M'Sik, University Hassan II of Casablanca, Morocco, B.P 7955 Sidi Othmane. She operates in several fields of educational sciences: educational technologies, engineering of distance education and didactics. She is a Member of the Observatory of Research in Didactics and University Pedagogy (ORDIPU) and the Multidisciplinary Laboratory in Sciences and Information Communication and Education Technology (LAPSTICE). She also coordinates works on digital learning: hybrid device, inverted classes, collaborative platforms, serious games, MOOCS, SPOCS, mobile learning, learning analytics and performance management

Mohamed Talbi is a PhD in Sciences and Processes of Analysis from the University Pierre et Marie Curie of Paris. He is currently the Dean of the Faculty of Sciences Ben M'Sik at Hassan II University, B.P 7955 Sidi Othmane, Casablanca, Morocco, and the Director of the Observatory of Research in Didactics and University Pedagogy (ORDIPU) since 2014. He is an Expert in the fields of teaching and research on educational technologies, engineering of the distance training, techniques of training, information systems. He is the author of several national and international awards and has accumulated more than 30 years of scientific productions

Abdelwahed Namir is a PhD in Numerical Methods for Engineers from Mohammadia School of Engineers (EMI Rabat) Morocco. He is also the Head of Laboratory of Technological Information and Modelisation (LTIM) Faculty of Sciences Ben M'Sik, University Hassan II - Casablanca, Morocco. His research interests include Mathematics, Computers, modeling....

Article submitted 24 June 2018. Final acceptance 16 July 2018. Final version published as submitted by the authors. 